\title{
THE ROLE OF LOCAL GOVERNMENT IN THE PROTECTION OF COPYRIGHT AGAINST CREATIVE INDUSTRY LOCAL CULTURAL HERITAGE IN SAWAHLUNTO CITY
}

\author{
Yulia Nizwana; Rifqi Devi Lawra \\ Faculty of Law, University Mahaputra Muhammad Yamin \\ Email: yulianizwana@yahoo.com
}

\begin{abstract}
Intellectual Property Rights (IPR) are closely related to the economic growth of a State. Appreciation and protection of intellectual works will create a conducive climate for the creativity and innovation of the people. IPR is a Right that is closely related to economic issues. IPR is identical with the commercialization of intellectual works. The commercialization of intellectual works in principle aims to generate economic benefits. Traditionally intellectual property is divided into two branches of "Industrial wealth" and "Copyright". Industrial Property includes the protection of the invention through a Patent, certain commercial protection through the laws of the mark and the laws of industrial design protection. In addition, industrial wealth includes unfair competition control. Traditional Knowledge as a Regional Asset that obtains Legal Protection, As set forth in the copyright law, in Article 10 paragraphs (1) and (2). The professional entity that has the right to decide may not be the copyright registration Copyright is an institution of IPR in each region and Higher Education. Such as the District and Municipal Trade Office, Provincial Trade Office as an extension of the Directorate General of IPR in Jakarta. Sawahlunto city is one of the cities in the province of West Sumatra Indonesia. Currently, the city of Sawahlunto develops into a multi ethnic old tourist city, making it one of the best old cities in Indonesia. The result of crafts from the work of the creation of the traditional community of Silungkang city of Sawahlunto is a cultural asset that needs to be protected under the Copyright Act. To get legal protection against the copyrights of the local creative industry heritage, is inseparable from the role of local government of course, where expected with the problems faced by the public to obtain legal protection of their copyrights. The purpose of this study is to know how the role of local government in the protection of copyright to the creative industry of local cultural heritage, and what are the constraints of local government in the protection of copyright to the creative industry of local cultural heritage in Sawahlunto city. It draws on empirical research method with qualitative approach and aims to describe the role of local government in the protection of copyright to the creative industry of local cultural heritage in Sawahlunto city. This study finds reveals that the local government still faces many obstacles, both in terms of juridical constraints or legal constraints as well as technical constraints.
\end{abstract}

Keywords: Role of Local Government, Protection of Copyright, Creative Industries Heritage of Local Culture. 


\section{A. INTRODUCTION}

Indonesia as an archipelagic country has a rich diversity of arts and cultures. The richness of art and culture is one source of intellectual works that can and should be protected by law. The wealth is not solely for the arts and culture itself, but can be utilized to enhance the trading and industry capabilities that involve its creators. Thus, the wealth of protected art and culture can improve welfare, not only for its creator but also for the Nation and the State (Adrian Sutedi, 2009: 51).

Intellectual property rights are closely related to the economic growth of a state. appreciation and protection of intellectual works will create a conducive climate for the creativity and innovation of the people. IPR is a right that is closely related to economic issues. IPR is identical with the commercialization of intellectual works. The commercialization of intellectual works in principle aims to generate economic benefits (Maryati Bachtiar, 2007: 61-67).

Traditionally intellectual property is divided into two branches of "Industrial wealth" and "Copyright". Industrial Property includes the protection of the invention through a Patent, certain commercial protection through the laws of the mark and the laws of industrial design protection. In addition, industrial wealth includes unfair competition control (Patiung Liling, 2014: 38-40).

Traditional Knowledge And Traditional Cultural Expression (PTEBT) Indonesia was born as a cultural product, whose process of creation was not once so but continued to evolve with the development of society and manifested in various works that are mastered and shared by all members of the community. In the present context, PTEBT can not only be viewed as a "heritage of ancestors" with a historical value that is treated only as a beautiful, ancient and antique display that adorns the corners of the house but has little contribution (Suyud Margono, 2012: 67).

The bridge between traditional knowledge as a product of innovation and creation of human morality with its economic and moral aspect is intellectual property which can be interpreted as a right derived from creative activity, a human 
mind power capability expressed to the general public in its various forms, which has benefits as well Useful in supporting human life, and economic value (Dwi Martini, 2014: 40).

In Indonesia one of the obstacles to be able to provide IPR protection is from the community itself, which on the one hand still thinks IPR is a "public right" which is a social function, because there are still many people who do not object if their products are imitated by others, Their products, there is a presumption of their products are great and interesting. The cultural attitudes of Indonesians who do not understand IPR fully and are not supported by adequate legal awareness often misunderstand that IPR protection is not in line with local culture (Imas Rosidawati Wiradirja, 2013: 47-50).

Traditional Knowledge as a Regional Asset that obtains Legal Protection, As set forth in the copyright law, in Article 10 paragraphs (1) and (2) (Riswandi Agus Budi : 2005) The professional entity that has the right to decide may not be the copyright registration Copyright is an institution of IPR in each region and Higher Education. Such as the District and Municipal Trade Office, Provincial Trade Office as an extension of the Directorate General of IPR in Jakarta (I Nyoman Lodra, 2012: $57)$.

Sawahlunto is one of the cities in West Sumatera province of Indonesia. Currently, the city of Sawahlunto develops into a multi ethnic old tourist city, making it one of the best old cities in Indonesia. Based on data from the Central Statistics Agency, Sawahlunto is the second lowest poverty rate in Indonesia after Denpasar City Bali. Sawahlunto also includes the second highest per capita income city in West Sumetera, where the livelihoods of the population are mostly sustained by the mining and service sectors and even some areas are being developed to become a central area of handicraft and snack industries.

So far, Sawahlunto city is known as a coal mining industry city, but now that coal mine is no longer promising for local people's life, the city government of Sawahlunto also glances at the potential of culture and craft that exist, such as Silungkang songket weaving craft. Weaving or weaving is the process of making 
cloth with woven yarn of feed between the thread of lungsi by using loom made of wood, bamboo stick and metal, from this process will be produced weave cloth and songket. One of the famous local songket weavers in West Sumatra Minangkabau is Silungkang, Silungkang Village is a village in the city of Sawahlunto. The village is also known for its arts such as rattan wicker crafts, canes, bamboo, broom, and weave. The weaving in Silungkang has a common type of Batabua, the decorated Songket does not meet the fabric area, and with some basic songket is very plain and some boxes. Silungkang woven motif comes from natural environment such as Rabuang Pucuak, flowers, birds motives, Sirangkak, Balah Katupek and others.

The problem faced on IPR protection of local creative heritage industry is the lack of knowledge and understanding of entrepreneurs or craftsmen on IPR especially in the field of Copyright is still a lot of traditional society or craftsmen in practice do not know the importance of the protection of copyright law to the result of his craft. Legal protection for every entrepreneur is certainly indispensable, not to the exception of the artisans of weaving in creating the motives of traditional woven cloth of good quality and durable of course issue all the energy, mind and funds are not small (I Gusti Agung Wisudawan 2010) The result of crafts from the work of the ideals of the traditional community of Silungkang city of Sawahlunto is a cultural asset that needs to be protected under the Copyright Act. To get law protection to the copyrights of the local creative industry heritage, is inseparable from the role of local government of course, where it is expected that the problems faced by the public to obtain legal protection of their copyrights. So far, local governments have focused only on improving the production process in order to improve the economy of the community, while the legal protection aspects are still neglected. From the above issues attracted the attention of researchers to examine how "The Role of Local Government In Protection of Copyright Against Creative Industry Local Cultural Heritage In Sawahlunto City" 


\section{B. PROBLEM STATEMENTS}

1. How is the Local Government's Role in Protection of Copyright Against Creative Industry Local Cultural Heritage In Sawahlunto City?

2. What are the constraints of Local Government in Protection of Copyright Against Creative Industry Local Cultural Heritage In Sawahlunto City?

\section{RESEARCH METHODS}

This research will discuss and examine the role of local government in the protection of copyrights to the local cultural heritage creativity industry in Sawahlunto city, the approach used in this research is the empirical legal approach (socio legal research) which looks to the rules as Reference and compare its implementation to the reality in the field. Namely the rules on the protection of Copyright to the results of the Creative Industry Local cultural heritage compared with the implementation in the city of Sawahlunto. This research will use techniques or methods of processing and analysis of qualitative data. The primary data required in this research is information related to the role of Local Government in Protection of Copyright to Creative Industry of Local Cultural Heritage In Sawahlunto City. Primary data can be searched through the search for information from relevant parties in the field, such as the Trade Office of Sawahlunto City, as well as creative industry craftsmen. To obtain primary data from respondents, this research will use semistructured interview method.

\section{LITERATURE REVIEW}

\section{a. Overview of Local Government}

\section{a. Understanding and governance of Local government}

With the enactment of Law Number 23 of 2014 on Local Government and In Invitation On October 2, 2014, the Law Number 32 of 2004 on The Local Government was revoked and declared no longer valid and the rules of implementation of Law Number 23 of 2014 should be determined. 
Among the amendments are the division of functions between the central government, provincial and district / municipality governments on governance affairs in the fields of forestry, marine and mineral resources, while secondary education affairs and especially the authority of the Provincial Government.

Law Number 23 of 2014 On Local Government in principle change the system of local governance, so that the area is directed to accelerate the realization of community welfare by improving services, empowerment and the role of society.

Definition of Local government in Law Number 23 of 2014 Article 1 :

1. Number 2 of the local government is the implementation of local government affairs and the regional People's Representative Council according to the principle of autonomy and assistance with the principle of autonomy as widely as possible in the system and principles of the Unitary State of the Republic of Indonesia as referred to in the 1945 Constitution of the Republic of Indonesia

2. Number 3 Local government is the head of the region as an element of local government administration that leads the implementation of government affairs which become the authority of the autonomous regions.

b. Concurrent Government Affairs

1) Compulsory governmental affairs related to basic services include: Education

2) Health

3) Public works and spatial arrangement

4) People's housing and residential area

5) Peace, public order, and protection of the people, and

6) Social

Mandatory government matters not related to basic services include: 
1) Labor

2) Health

3) Child empowerment and child protection

4) Food

5) Land

6) Environment

7) Population administration and civil registration

8) Community and village empowerment

9) Control of population and family planning

10) Transportation

11) Communication and informatics

12) Cooperatives, small and medium enterprises

13) Investment

14) Youth and sports

15) Statistics

16) Coding

17) CultureLibrary and

18) Filing

Preferred governmental affairs include:

1) Marine and fisheries

2) Tourism

3) Agriculture

4) Forestry

5) Energy and mineral resources

6) Trade

7) Industry 
8) Transmigration.

c. The meaning of the autonomous region is the unity of the legal community which has the boundaries of the territory which is authorized to regulate and manage the affairs of the government and the interests of local people according to their own initiative, based on the aspirations of the people in the system of The Unitary State of the Republic of Indonesia (Siswanto Sunarno, 2005: 89).

Within Autonomous Region there are elements as:

1) Elements boundary area

2) Unsure (element) of government

3) Community Elements.

2. Introduction Intellectual Property Rights (IPR)

a. Understanding and Regulation of IPR

According to Sri Rejeki Hartono IPR is a right that has special and special characteristics because this right arises only if there is a grant of state over that right which the state gives this right to the person giving birth to an intellectual work based on what is stipulated in the provisions of state law.

IPR elements

1) Born from human intellectual ability

2) Absolute (Exclusive)

3) Has a value of benefits

4) Not material

Based on state appointment

b. Background The birth of IPR

1) The existence of legal issues related to IPRs that require legal arrangement

2) The emergence of various intellectual works that require the protection of the law

3) It makes intellectual work as an asset in industry and commerce 
4) The more complex problems in the world of commerce that require a more comprehensive regulation of various issues including issues related to IPR

5) The occurrence of globalization in various aspects (borderless world)

c. IPR protection

Protected IPRs are Intellectual Works that have been tangible or applicable based on IPR fields (Sri Redjeki Hartono, 2008: 87)

1) Copyright (Author Right)
a) Art
b) Literature
c) Science
d) Related Rights (Performers, Records, etc.)

2) Industrial Property

a) Patent (Technology Invention)

b) Brand (Symbol / Trade Name of Goods / Services)

c) Industrial Design (Product Appearance Design)

d) Layout Design of Integrated Circuit (Integrated Circuit Laying / IC Design)

e) Trade Secrets (Confidential Information that has economic value)

f) Plant Variety Protection (PVT) (managed by Ministry of Agriculture)

d. International Agreement

1) Berne Convention 1883 (Copyright)

2) Paris Convention 1886 (Industrial Property)

3) Agreement on Establishment of WTO - TRIPS 1994

e. Ratification of the International Law Provisions on Intellectual Property Rights 
1) Presidential Decree Number 15 of 1997 concerning Presidential Amendment Number 24 of 1979 on the Ratification of the Paris Convention for the Protection of Industrial Property

2) Presidential Decree. Law Number 16 of 1997 on the Validation of Patent Cooperation Treaty (PCT) and Regulation Under the PCT

3) Presidential Decree Number 17 of 1997 on Ratification of Trade Mark Law Treaty

4) Presidential Decree. 18 of 1997 on the Validation of the Bern Convention for the Protection of Literary and Artistic Works

5) Presidential Decree Number 19 of 1997 on Ratification of WIPO Copy Right Treaty

6) Law Number 7 of 1994 on the ratification of Agreement Establishing The World Trade Organization

f. National Intellectual Property Law

1) Law Number 28 of 2014 on Copyright

2) Law Number 14 of 2001 on Patents

3) Law Number 15 of 2001 on Marks

4) Law Number 30 of 2000 on Trade Secrets

5) Law Number 31 of 2000 on Industrial Design

6) Law Number 32 of 2000 on Layout Design of Integrated Circuit

7) Law Number 29 of 2000 on Plant Variety Protection

3. A Public Review of Copyright

a. Setting and copying Copyright

Copyright is regulated in Law Number 28 of 2014 on Copyright in lieu of Law Number 19 of 2002, the enactment of Law Number 28 of 2014 is an attempt by the government to protect the economic rights and moral rights of 
the creators and other related parties. The new law also has a passion to support all creators and business actors to be more creative to give birth to the workshop. The spirit to work is expected to improve the competitiveness of our creativity in order to face the ASEAN Economic Community (MEA) which is already soon (http://reqiusitoire-law Enforcement \& justice magazine, accessed on Juny 27, 2017).

The new law has a breakthrough, if the old law, Law Number 19 of 2002 only 76 Articles, the New Law has 126 Articles or changed / revised up to 60 percent. The new law has the spirit of change with various reforms.

Definition of Copyright In Article 1 point 1 is an exclusive right for the creator or recipient of the right to announce or reproduce his or her creation or grant permission to it without prejudice to restrictions under applicable legislation.

Copyright in Indonesia recognizes the concept of "economic rights" and "moral rights", economic rights are the right to economic benefits to creation, while moral rights are the inherent right of the creator or performer (art, recordings, broadcasts) that can not be eliminated With any reason, even if copyright or related rights are transferred.

\section{b. Traditional Cultural Expressions and protected creations}

The copyright of Traditional cultural expression is held by the State, the State shall oblige to inventory, preserve and select the expression of Traditional culture. As mentioned in Article 38 Paragraph (1) and (2) of Law Number 28 of 2014 About Copyright. Then in Article 40 mentioned about the creation protected in the Field of Arts and Literature, consisting of:

1) Books, pamphlets, perwajahan, published papers, and all other written works

2) Spell, lecture, speech and other similar creations

3) Props made for educational and scientific interest 
4) Song / and or music with or without text

5) Drama, musical drama, dance, choreography, puppetry, and pantomime

6) Works of art, in all forms such as painting, drawing, carving, calligraphy, sculpture, sculpture or collage

7) Works of applied art

8) Architectural works

9) Map

10) Art work of batik or other motif art

11) The work of photography

12) Portrait

13) Cinematographic works

14) Translation, interpretation, adaptation, arrangement, modification, and other works of transformation

15) Translation, adaptation, arrangement, transformation, or modification of traditional cultural expression

16) Compilation of creation or data, whether in a format that can be read with computer programs or other media

17) The compilation of traditional cultural expression during the compilation is the original work

18) Video games, and

19) Computer program.

4. General Review of Creative Industries Local Culture

a. Understanding Creative Industries

The creative industry is the industry producing output from the utilization of creativity, expertise and individual talents to create added value, employment and quality of life improvement. While the creative economy based on local culture is an economy that relies on the creativity of the 
community by exploiting the potential of local culture that is available to be utilized as capital in obtaining profit.

Seeing the diversity of culture owned by this nation and each region has its own uniqueness. Importantly, for the direction of creative economy more developed with local culture-based, culture should be the basis of its development. In other words, there is a good potential based on local genius in the culture of every region in Indonesia this needs to be appreciated, lifted, and manifested into the program of creative economy (http:// www.medanbisnisdaily.com/m/news/read/2014/08/07110038/industri kreatif-kreatifberbasis-budaya-lokal, accessed on Juny 2, 2017).

The form of local culture that is spread are:

1) Custom house

2) Dance, music and musical instruments

3) Statue

4) Clothing

5) Literature / writing

6) Food

These cultural forms characterize the creativity that is embedded in it and is supported by the creative environment that lasts between generations. When the development of creative industry has a cultural base it will be a source of continuous inspiration (Usman Rianse, dkk, 2010: 38). In the development of the culture of government should be able to develop all the potential of local culture to grow and develop in balance so that will create harmonization of local culture to sustain the development of national culture. The government also acts as a facilitator in providing capital in the form of funds, facilities and infrastructure, the development of quality human resources and the establishment of a solid quality network between creative industry players, technology practitioners and the business world as well as 
providing information and technology needs. The main role must be supported by the guarantee of IPR protection from the design of the Creative Industry.

\section{E. RESEARCH RESULT AND DISCUSSION}

1. The Role of Local Government in Protection of Copyright Against Creative Industry Local Cultural Heritage In Sawahlunto City.

Indonesia is very rich in local culture that has the advantage of products derived from biodiversity. And it is very certain that this product can compete or have competitive advantages compared with other countries products because it has clear characteristics and is not owned by other countries. There are several benefits that will be achieved from the protection of creative industries of local cultural heritage as a superior and competitive product that is, in terms of utilization of raw materials, Indonesia will not experience shortages because, not only rich in culture, Indonesia is also rich in natural resources that can be made By the community as a raw material of industry products with high selling value. The next advantage, will open the opportunity to try as far as possible to the public to find a source of income from local creative heritage culture industry that has existed from generation to generation with the utilization of natural resources that exist around the area where they live.

With the existence of government intervention in the protection of local cultural heritage will be able to preserve and revive the local cultural identity that began eroded by foreign culture, the next advantage is the more affordable potential of the existing -remote areas, because it is not closed the possibility of local products From remote areas in Indonesia has a uniqueness that can be worth a very high sale, so encouraged his craftsmen who are in the area will automatically stretch the economic growth towards the welfare of the community evenly to the areas.

From the economic point of view, Indonesia is expected to be able to compete and rise in the economic field that is triggered by the beauty of tradition 
and diversity of local cultural heritage. And here is needed the role of government both in terms of management and utilization and that is not less important in terms of aspects of his law. The role of law is very important, so as not to neglect the rights of local communities. Cultural heritage as a form of traditional knowledge and traditional cultural expression of the local Indonesian community, whether in the form of traditional technology or cultural expression such as music, dance, painting or other art, architecture, weaving, Batik, story and legend.

Pursuant to the explanation of Article 38 Paragraph (1) of Law Number 28 of 2014 on Copyright the meaning of "Traditional cultural expression" includes one or a combination of forms of expression as follows:

1) Verbal textual, both oral and written, in the form of Prose and Poetry, in various themes and content of messages, which can be either literature or informative narrative

2) Music, including, among others, vocal, instrumental, or a combination thereof

3) Motion, including among others, dance.

4) Theater, including among others, puppet shows and folk plays

5) Art, both in the form of two dimensions and three dimensions made of various materials such as porters, wood, bamboo, metal, stone, ceramic, paper, textiles, etc. or any combination thereof; and

6) Traditional ceremonies.

In Chapter V Part One Law Number 28 of 2014 concerning Copyright is expressed by Traditional Cultural Expression and Copyrights of a creator whose author is unknown paragraph (1) the copyright on the traditional expression held by the State, paragraph (2) Inventory, safeguard, And maintain the traditional cultural expression as referred to in subparagraph (1), then in paragraph (3) the use of traditional cultural expression as referred to in paragraph (1) shall take into account the living values of the victims community, paragraph (4) further 
provisions concerning the rights Copyrights held by the State over traditional cultural expressions as referred to in paragraph (1) shall be governed by a Government Regulation. Based on the sound of the article, in this case government is the role of representing the State to provide protection of the Law on the copyrights of traditional cultural expressions.

Through the protection provided in the field of IPR is expected to ensure that artists can enjoy freedom of expression, and can enjoy a condition, where they can create new creations in the tradition concerned, and can inherit the creative ability of the generation-generation. Protection in the field of IPR is also highly expected as an effort to protect against unauthorized use by foreign companies that use the cultural heritage of a society but then claim as their individual property.

Perpetrators and artisans in Indonesia have experienced issues related to IPR claims over local cultural heritage. That is the reason why the protection of law is important especially for the utilization of creative industries local cultural heritage as an economic source in Indonesia.

Sawahlunto city is one of the area in western Sumatera which has many creative local cultural heritage industry which become one of income source for its society. Type of creative industry local cultural heritage, among others, Songket, Umbrella paper, Coal Handicraft, Bamboo Woven etc.

In the copyright law stated "The State shall inventory protect and protect the traditional cultural expression, in the law is not explicitly stated who the affiliates of the State, therefore the role here is the local government in the middle of the community to conduct an inventory of local cultural heritage The. In this case Regional offices of the ministry of justice and human rights an extension of the Directorate General of IPR encourages every district and city government to conduct the inventory, the inventory result will be sent Regional offices of the ministry of justice and human rights then made a data base which then proceeded 
to the Directorate General of IPR to do data collection nationally with the aim Any local cultural expression or creative industry of local cultural heritage is legally protected.

Note by the community with the registered right of its results intellectual work they will gain several advantages, namely with the registration of their legally protected, the selling price will increase the economic benefits for the community, and can be used as evidence in the court case of its Issues in the field of IPR is for consideration for the judge to win the dispute from the holder of IPR.

So far the role of the city government Sawahlunto in providing copyright protection of creative industry heritage of the local culture in terms of inventory have been very good, In Department of industrial and trade cooperatives was in inventory in the form of a book catalog Songket Silungkang cultural heritage of the Old City of Sawahlunto which contains the history songket, ornamentation typical songket And it can also be found in the office of culture and museum of Sawahlunto city.

The role of the local government of Sawahlunto city in the inventory is good enough, but has not encouraged the community towards copyright registration. Only the local government town Sawahlunto more focus on production activities alone that is how the quality of his production is increasing, getting better, more smoothly and grow through development of industry of small and medium enterprises in the form of "technical training songket for society" and the results are already Many new creations created from the style of the songungket silungkang. And the work actually need the urge to immediately register with the copyright to the manifestation of the idea of community associated with a new twist of the Silungkang songket. Surely as long as it's really worth the innovation and it's never been there before.

This activity has been started from 2012 until now, conducted in areas or villages that recommend through proposals Department of industrial and trade 
cooperatives to be training and approved depending on the quota that has been budgeted by cooperatives totaling 41 people from 2012-2016, up so 50 people in 2017. The targets of this program are poor people, drop out children and housewives.

The government's efforts towards the protection and encouragement for registration of its Copyright is still not maximal, plus the socialization which is highly expected by the local government from the Directorate General of IPR or at least his extension of his hand by Regional offices of the ministry of justice and human rights very limited. So the public does not get the education that pushes them towards how the importance of law protection from the local cultural heritage creative industry.

Basically there are some disadvantages here, where the State really does not want the intellectual property created by the child of his people stolen or claimed by a foreign country, but the State did not provide a good strategy and the maximum how to avoid the occurrence of such misery. And indeed the role of the government in this case should be like picking up the ball, providing active protection is not like what happens today is still in the form of protection of passive, waiting from the community while the community itself and even the local government did not get a good socialization. From the economic point of course very give and very good for the welfare of society, especially Sawahlunto City, would be better if given good protection also in terms of its law through copyright protection. The weakness here is the role of the government is still not maximized in terms of encouraging the protection of the creative industry's copyright of local cultural heritage in Sawahlunto city, and still not maximizing the socialization of copyright law from the Directorate General of Intellectual Property Rights or related to the districts and cities and local communities, Do not understand what is importance of registration, how the procedure, and what are the benefits. 
The very serious thing that should be of concern to the local government of Sawahlunto city is the need for concrete plans to facilitate the protection of the local cultural heritage in Sawahlunto city, to protect the people from the claims of other States which would certainly be very likely to steal and then claim their property, and Finally we have to pay royalty to them, while it is the result of the expression of our local culture. The problem of traditional knowledge protection and cultural expression is commonly associated with intellectual property protection systems in order to support artists in practicing and developing the arts and traditions. It should ensure that artists enjoy the freedom of expression, create new works, and pass on to the next generation.

Under the provisions of Chapter V of Law Number28 of 2014, with respect to the role of Local government in the protection of the Creative Industry Local Cultural Heritage of the City of Sawahlunto, the Related Office has performed a good Inventory pursuant to Article 38 but is merely inventory locally for the benefit of trade, There is further action towards the protection, where it should after inventory of the copyrighted works that no longer found its creator in accordance with Article 39 of the State in this matter represented by the local government together with Regional offices of the ministry of justice and human rights West Sumatera do inventory to stakeholders for example to Local Tourism Department to Looking for data Copyright local area, as well as search for potential areas, can also to the Office Department of industrial and trade cooperatives Regional District and City.

From the results of the research, it is known that the role of local government has not yet toward the protection of law, is still limited to the maintenance in order to increase the potential of creative industries of local cultural heritage towards the increase of production to increase the speed of economic growth in Sawahlunto city, how good is the economic growth in line with the existence Local government efforts to provide legal protection, so as well 
as get the same benefits, because with been protected by law automatically higher selling value will be useful to encourage the growth of economic growth.

Regional offices of the ministry of justice and human rights in West Sumatera As an extension of the Directorate General of Intellectual Property Rights has a role to perform:

1) Providing socialization to the public to appeal to the public to register, with the registered intellectual property rights of the community will get benefits such as, Protected by law, the sale value will increase, and may be judge consideration as evidence to win the copyright.

2) The Regional Office shall also forward the application for registration which has been entered to be forwarded to the Director General of HAKI

Legal Protection granted to the Subject of this Law into the form of a device that is both preventive and repressive, both oral and written. In other words, the protection of law as a separate feature of the legal function itself, which provides the concept of justice, certainty, benefit and peace, as well as what is expected by the public in obtaining legal protection in the field of Copyright which is the exclusive property of their intellectual property.

Legal protection from the role of government as a related agency that is obliged to protect the copyright of local cultural heritage can also be done through implicit protection is protection produced by effective supervision and coaching, which can avoid the occurrence of legal problems. In the following way:

1) Legislation of Intellectual Property Rights in This also includes the Copyright Act

2) Protection generated by effective supervision and guidance, which the Directorate General of IPR or related Office to the district and city level 
3) Efforts to maintain the viability of the Creative Industry Creative The local cultural heritage as an institution in particular and the protection of its overall HAKI protection system in general

4) Maintaining the level of continuity of development of local creative heritage Culture Industry

5) Doing business towards the improvement of legal protection in accordance with the principle of justice in intellectual property

6) How to provide legal protection that does not harm the local community

7) Provide clear and accessible information by local communities

The second is explicit protection: protection through the establishment of an institution that guarantees the legal certainty of the copyrights of Local Cultural Heritage, so that if the copyright holder experiences his or her missal claim by another person, or the State, the institution will facilitate the community in dispute settlement Are directly and indirectly protected. Hopefully in the future all local government really give protection especially for local cultural expression which is intellectual of society which need to be protected so that society get benefit from facet of Economic and Economy to spur Economic growth rate.

2. Local Government Constraints In Protection of Copyright Against Creative Industry Local Cultural Heritage In Sawahlunto City.

In carrying out its role the local government still faces many obstacles, both in terms of juridical constraints or legal constraints as well as technical constraints. IPR is expected to become a component of national development support. IPR is also needed in the framework of developing human resources (HR), including the development of local potential, With abundant natural resources Indonesia can rely on it as a supporter of National development. So how the natural resources owned by Indonesia is managed independently by 
Human Resource Indonesia Self. In the implementation of its protection in Sawahlunto City there are several obstacles encountered as follows:

a. Juridical constraints or legal constraints

1) The lack of public knowledge on the conception of IPR protection is due to the very poor socialization of the Copyright Act of the IPR Directorate General or the related offices of the Provincial Level to the Local government of Sawahlunto City or the public, the City Government of Sawahlunto expects in this matter to the directorate General of Intellectual Property Rights Giving socialization such as ball pick up, for example by making program in provincial level and invite every Regency And City, or vice versa those coming to regency and city to give socialization, so if from representative come to the district and city, hence special service will be willing to facilitate by inviting all Craftsmen, so that the target, but if it is held at the Provincial level then the coming may only be representative only. So there is still a weakness in the case of people less get socialization of various provisions relating to the Protection of Intellectual Property.

2) The delay in realizing the Law Plan relating to the Copyright of creative industry of local cultural heritage so that the Municipal Government and Society do not know about the Intellectual Property Rights Act, but there are things that need to be paid attention by the government in pushing towards the protection of law on copyright This is for a reason (Edy Satriya, 2003: 80).

a) Indonesian society is still relatively poor and is struggling to get out of the crisis, abundant natural resources in the city of Sawahlunto is actually one source to spur economic growth, but of course coupled with the maximum legal protection as a companion. 
b) Our human resources are still left behind, Human resources are expected to manage well the abundant natural resources as potential local wealth.

c) Increasing unemployment rate

d) Operational costs for law enforcement for police officers and related agencies available are very limited.

e) Illegal products are still sold freely, let alone in the field of copyright, we still find free sale in the market of illegal products without getting consistent and assertive action from the government and related institutions.

f) Advancement in the field of telematic form of convergence of computer communication technology and multi media that became the trigger of the new economy has opened almost limitless opportunities to piracy other people's work.

3. Community and City Government Sawahlunto not too understand The registration process Copyright is also high cost. Please note Registration of Intellectual Property Rights conducted by the local government is still easier than individuals.

a. Technical constraints

The concept of communal rights is still inherent in the Indonesian society, this is one of the factors that causes less awareness to provide legal protection against intellectual property against each of his area.

In terms of facilities and infrastructure does not obstacles, it's just in this case that is a constraint is the Fund that has not been included into the budget of the city government for protection and development issues Copyright is. The budgeted leads to the production process, how can the local community increase its production to spur economic growth, eradicate poverty, reduce unemployment, and increase the income of Sawahlunto. 
Besides, the community and the city government of Sawahlunto are still pessimistic to register the songket style for example, due to many similarities with other songket motifs.

\section{F. CLOSING}

\section{Conclusion}

a. The Role of Local Government In Protection of Copyright Against Creative Industry Local Cultural Heritage In Sawahlunto City.

The role of Sawahlunto municipal government in providing copyright protection from the local cultural heritage creative industry in terms of inventory is very good. In the Office of Department of industrial and trade cooperatives was in inventory in the form of catalog Songket Silungkang Sawahlunto Old Town cultural heritage that contains the history songket ornament typical songket Silungkang, and it can also be found in the office of culture and museum of Sawahlunto city.

The role of the local government of Sawahlunto city in the inventory is good enough, but has not encouraged the community towards copyright registration. Only the local government town Sawahlunto more focus on production activities alone that is how the quality of his production is increasing, getting better, more smoothly and grow through development of industry of small and medium enterprises in the form of "technical training songket for society" and the results are already Many new creations created from the style of the Silungkang Songket. And for the work actually need the urge to immediately register with the copyright to the manifestation of the idea of community associated with a new twist of the Silungkang songket. Surely as long as it's really worth the innovation and it's never been there before.

b. Obstacles Local Government In Protection of Copyright Against Creative Industry Local Cultural Heritage In Town Sawahlunto. 


\section{Juridical constraints or legal constraints}

a) The lack of public knowledge on the conception of IPR protection is caused by the very poor socialization of the Copyright Act of the IPR Directorate General or the related offices of the Provincial level to the Local government of Sawahlunto City or the community.

b) The delay in realizing the Law Plan relating to the Copyright of creative industry of local cultural heritage so that the Municipal Government and Society do not know about Intellectual Property Rights Act.

c) Community and City Government Sawahlunto not too understand The registration process Copyright is also high cost. Please note Registration of Intellectual Property Rights conducted by the local government is still easier than individuals.

2. Technical constraints

In terms of facilities and infrastructure is not an obstacle, only in this case the obstacle is the Fund that has not been included into the budget of the City Government for the issue of protection and development of Copyright. The budgeted leads to the production process, how can the local community increase its production to spur economic growth, eradicate poverty, reduce unemployment, and increase the income of Sawahlunto. Besides, the community and the City Government of Sawahlunto are still pessimistic to register the songket style for example, due to many similarities with other songket motifs.

\section{Suggestions}

Suggested to Local Government of Sawahlunto City to be more active:

a) About the importance of legal protection of creative industry inheritance Local Culture in cooperation with other relevant agencies. 
b) Included into Local Government Budget Funds required for registration of local creative industries of cultural heritage that lead to the protection of the Law for the people.

c) Local Government of Sawahlunto City Must be more Optimistic to bring their society to get legal protection against Local Creative heritage creative industries.

\section{BIBLIOGRAPHY:}

\section{Books and Journals:}

Adrian Sutedi, 2009, Hak Atas Kekayaan Intelektual,Jakarta, Sinar Grafika, Jakarta.

Dwi Martini, Tahun 2014, Pemenuhan Hak-hak ekonomi Dan Moril Masyarakat Asli Atas penngtahuan Tradisional dan Ekspresi Budaya Tradisional Melalui Sistim IPR Di Indonesia, Jurnal IUS, Vol II No 6.

Edy Satriya, Dilema Penerapan UU Hak Cipta, Majalah Masa, Edisi 11, Tanggal 7 Oktober 2003.

I Gusti Agung Wisudawan, Tahun 2010, Perlindungan Hak cipta Kain tenun Tradisonal Khas Lombok Menurut UU Hak Cipta Tahun 2002 Dikabupaten Lombok Tengah, GaneC Swara, Vol4 Number1.

Imas Rosidawati Wiradirja, Tahun 2013, Konsep perlindungan pengetahuan Tradisional berdasarkan asas keadilan melalui Sui Generis Intellectual Property System, Jurnal Hukum IUS QUIA IUSTUM, Vol 20 No 2.

I Nyoman Lodra, Tahun 2012, Perlindungan pengetahuan Tradisional Dan Praktek Hak Kekayaan Intelektual (Haki), URNA Jurnal Seni Rupa, Vol 1 No 1.

Maryati Bachtiar. Tahun 2007, Pelaksanaan Hukum Terhadap Merek Terkenal (Well Known Merk) dalam WTO-TRIPs dikaitkan Dengan pengaturan Dan Praktiknya Di Indonesia, Jurnal Hukum Respublica, Vol 6 Number2. 
Usman Rianse,Wa K uasa, Weka Gusmiarty Abdullah, Peran Pemerintah Dan Perguruan Tinggi Dalam Pengembangan Ekonomi Kreatif Berbasis Budaya Lokal

Patiung Liling, 2014, Implikasi Perlindungan Hukum Hak Kekayan Intelektual Terhadap Perolehan Manfaat Ekonomi, Artikel Tesis, Program Studi Ilmu Hukum Pasaca Sarjana, Universitas Atma Jaya Yogyakarta.

Riswandi Agus Budi, 2005, Hak Kekayaan intelektual Dan Budaya Hukum, Jakarta, PT Raja Grafindo.

Siswanto Sunarno, 2005, Hukum Pemerintahan Daerah di Indonesia, Sinar Grafika, Jakarta.

Sri Redjeki Hartono, 2008, Perlindungan Hukum terhadap lisensi Paten, Tesis, Program Pasca Sarjana Ilmu Hukum Universitas Diponegoro, Semarang.

Suyud Margono, Tahun 2012, Prinsip Deklaratif Pendaftaran Hak Cipta; Kontradiksi Kaedah Pendaftaran Ciptaan Dengan Asas Kepemilikan Pubilkasi Pertama Kali, Jurnal RechtsVinding, Volume 1 No 2.

\section{Regulation:}

Law of the Republic of Indonesia Number 28 of 2014 on Copyright

Law of the Republic of Indonesia Number 23 of 2014 on Local Government

\section{Internet:}

http//reqiusitoire-law Enforcement \& justice magazine.

http// www.medanbisnisdaily.com/m/news/read/2014/08/07110038/industri kreatifkreatif-berbasis-budaya-lokal/ 